\title{
A kora gyermekkori intervenció és fejlesztési lépései
}

\author{
KeREKI Judit \\ Családbarát Ország Nonprofit Közhasznú Kft., Eötvös Loránd Tudományegyetem
}

\begin{abstract}
A gyermekek, köztük a speciális támogatást igénylö gyermekek és családjaik a kora gyermekkori intervenció rendszerében kapják meg azokat az ellátásokat, szolgáltatásokat, amelyek sajátos szükségleteik alapján megilletik öket. A korai életszakaszban nyújtott prevenciós és intervenciós szolgáltatások kiemelt jelentöségüek a gyermek fejlödése és a társadalom jövője szempontjából. A kora gyermekkori intervenció elméleti kereteinek meghatározása, a nemzetközi trendek áttekintése, a hazai intézményrendszer felépitésének, az ágazatközi együttmüködés jelen helyzetének leirása segiti az ellátórendszer fejlesztési lépéseinek áttekinthetöségét. A nemzetközi tapasztalatokra és a korábbi kutatási, fejlesztési eredményekre épitve a kora gyermekkori intervenció ágazatközi fejlesztését célzó projekt az egységes, áttekinthetö gyermekút kialakitását valósitja meg.
\end{abstract}

Kulcsszavak: kora gyermekkori intervenció, ágazatközi együttmüködés, szabályozott gyermekút, integrált-koordinált szolgáltatói rendszer, interdiszciplináris team

\section{Bevezetés}

A korai gyermekévekben zajló folyamatok komoly hatást gyakorolnak a későbbi életévekre, a gyermeket körbevevő tárgyi, személyi környezet, a gondoskodó kapcsolatok, az egészséges testi-lelki fejlődés érdekében végzett tevékenységek jelentősen befolyásolják a jövőbeni életminőséget. Reményt keltő, hogy hazánkban az utóbbi évtizedben a szakpolitikában és a fejlesztéspolitikában is egyre több figyelem fordul a kora gyermekkori intervenció ügye felé. Az ellátórendszer működését vizsgáló kutatások több olyan problématerületet azonosítottak, amelyek utat nyitottak a diagnózis alapú fejlesztések számára, a különböző ágazatokban zajló projektek egy hatékonyabban működő kora gyermekkori intervenciós rendszer kialakítását célozzák, a szakpolitikai elképzelések mentén és azokra hatást gyakorolva.

A korai ellátórendszer fejlesztési lépéseinek megvalósulása szempontjából fontos a kora gyermekkori intervenció elméleti kereteinek meghatározása, a korai beavatkozások fontosságának evidenciaalapú indoklása és tudatosítása. A nemzetközi trendek áttekintése, a hazai intézményrendszer felépítésének, az ágazatközi együttműködés jelen helyzetének leírása segíti az ellátórendszer fejleszté- si lépéseinek áttekinthetőségét. Az érintett gyermekekhez és családjaikhoz eljutó, szükségletalapú szolgáltatásnyújtás érdekében a különböző támogatórendszerek együttműködésének összehangolására, a szülöknek mint partnereknek a bevonására is szükség van. A szükségletekhez igazított, egyénre szabott szolgáltatási rendszer kialakítását célzó fejlesztések segítik a résztvevő szakembereket abban, hogy munkájuk során képesek legyenek a gyermeket, a családot és a szélesebb társadalmi környezetet rendszerben szemlélő, holisztikus megközelítés alkalmazására.

\section{A kora gyermekkori intervenció értelmezése}

A kora gyermekkori intervenció fogalmát nem csak a nemzetközi, de a hazai színtéren is eltérően használják. Az utóbbi években a különböző értelmezések szintézisének segítségével egy komplexebb megközelítés nyert teret, amely a European Agency for Special Needs and Inclusive Education (EASNIE, magyarul: Európai Ügynökség a Sajátos Nevelési Igényű Tanulókért és az Inkluzív Oktatásért) meghatározását és a hazai definíciók egymásra épülő eredményeit figyelembe véve ad szélesebb értelmủ jelentést. 
A kora gyermekkori intervenció és fejlesztési lépései

Ennek megfelelően a kora gyermekkori intervenció magában foglalja a pre-, illetve perikoncepcionális időszak preventív jellegü szolgáltatásait, valamint a fogantatástól a gyermek iskolába lépéséig a gyermekekre és családjaikra irányuló ellátások szolgáltatások összességét. Beletartozik minden olyan tevékenység, amely a gyermekek és családjaik speciális támogatását szolgálja. A kora gyermekkori intervenció három szinten zajlik, a gyermek személyes fejlődése, a család saját kompetenciájának megerősítése, valamint a gyermek és a család szociális befogadása érdekében. A kora gyermekkori intervenció a szűrés szakaszától, a probléma felismerésétől és jelzésétől kezdve az állapotmegismerésen, diagnosztizáláson keresztül magában foglalja a különböző habilitációs/rehabilitációs, a (pszicho)terápiás, valamint a gyógypedagógiai tanácsadó, korai fejlesztő és gondozó tevékenységet, illetve a juttatások rendszerét is. Szemléletében kiemelten fontos a prevenciós elem, beleértve a mentális egészséget, a viselkedésszabályozást veszélyeztető kapcsolati mintázatok kedvező befolyásolását (Kereki, 2015a; Kereki és Szvatkó, 2015; Kereki, 2017).

A gyermek korai életszakaszában nyújtott ellátások, szolgáltatások az egészségügyi, köznevelési, szociális, gyermekjóléti, gyermekvédelmi, valamint a család- és ifjúságügyi területekhez kapcsolódnak. Lehetnek általánosan hozzáférhetőek, azaz univerzálisak, ilyenek pl. a védőnői szolgáltatás, a bölcsődei gondozás-nevelés, illetve célzottan több különböző, speciális támogatást igénylő csoportra fókuszálók (pl. a pedagógiai szakszolgálat által nyújtott tevékenységek, mint a korai fejlesztés vagy a nevelési tanácsadás.)

\section{A kora gyermekkori intervenció célcsoportjai}

A kora gyermekkori intervenció célcsoportjába minden gyermek és családja beletartozik, beleértve

1. a biológiai rizikóval élo", illetve a biológiai (organikus) szinten érintett: a fejlödési rizikóval született, a sérült, eltérö vagy megkésett fejlődésü, fogyatékos, valamint a krónikus beteg és ritka beteg;

2. a pszichés fejlödés szempontjából sérülékeny;

3. a szociálisan hátrányos helyzetü (HH, HHH), valamint

4. a kiemelten tehetséges

gyermekeket és családjaikat (lásd 1. ábra). Ezek a csoportok differenciált szükségleteik alapján kapják az ellátást, sokszor azonban egymást átfedő halmazokat alkotnak, egyszerre többféle szükségletet generálva, amely rávilágít arra, hogy miért van szükség a korai beavatkozások komplex megközelítésére.

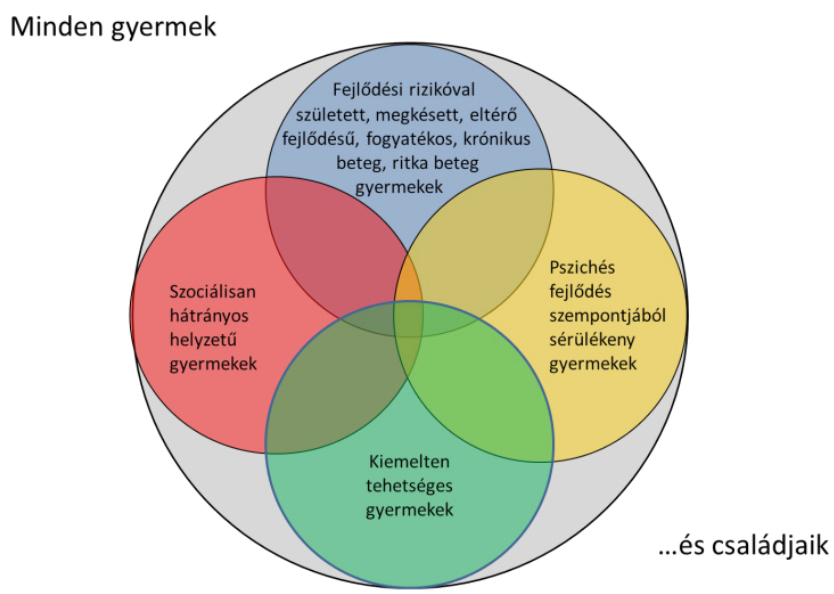

1. ábra: A kora gyermekkori intervenció célcsoportjai (Kereki, 2015 nyomán) 
A biológiai szinten érintett gyermekek körében találjuk a fejlődési rizikó miatt preventív ellátásra jogosultakat. A korai fejlődést veszélyeztető biológiai meghatározottságú rizikótényezők közül az egyik leggyakoribb a koraszülöttség.

A felismert vagy detektált problémák esetén a legkorábbi életszakaszba tartozó kisgyermekek esetében nem szívesen használjuk a fogyatékosság kifejezést. A 0-3 éves korosztály döntő többségének esetében az irányadó szakmai álláspont a fogyatékosságcsoportba való besorolást kevéssé tartja relevánsnak. A korai organikus sérülések inkább csak rizikótényezőkként azonosíthatóak, nem tudjuk, milyen kimenetei várhatók a különböző állapotoknak a beavatkozások hatására. Így inkább eltérő, megkésett fejlődésröl beszélünk. Eltérő fejlődés lehet a fogyatékosságot eredményező állapotok, pl. a szindrómák, a központi idegrendszer rendellenességeinek következménye, de a motoros funkciók, a hallás-, látás-, beszéd-, a kognitív funkciók atipikus fejlődése esetében is az átlagtól eltérő vagy megkésett fejlődésű csoportokról beszélünk. A biológiai hátránnyal, illetve rizikóval élő gyermekek körét részben lefedi a sajátos nevelési igényü kategóriába besorolt gyermekcsoport ${ }^{1}$, ahová a diagnosztizált fogyatékos gyermekek tartoznak.

Krónikus beteg gyermekek ellátása elsődlegesen az egészségügyi ágazathoz kötött, ám megkerülhetetlen ellátásuknak bio-pszichoszociális kontextusban való értelmezése. Hosszan tartó, általában lassú progressziójú betegségek sorolhatóak ide, amelyek sokszor a korai életévekből eredeztethetőek ( $W H O$, 2005). A gyakoriság alapján elsősorban a kardiovaszkuláris megbetegedések, a daganatos

\footnotetext{
${ }^{1}$ A jogszabály értelmében sajátos nevelési igényű az a gyermek, tanuló, aki a szakértői bizottság szakértői véleménye alapján mozgásszervi, érzékszervi (látási, hallási), értelmi vagy beszédfogyatékos, több fogyatékosság együttes előfordulása esetén halmozottan fogyatékos, autizmus spektrum zavarral vagy egyéb pszichés fejlődési zavarral (súlyos tanulási, figyelem- vagy magatartásszabályozási zavarral) küzd (2011. évi CXC. törvény a nemzeti köznevelésröl, 4. \$, 25).
}

betegségek, a krónikus légzőszervi megbetegedések és a diabétesz kerülnek fókuszba. (Busse és mtsai, 2010; GYEMSZI, 2013). A krónikus beteg gyermekek egy része ritka beteg. Minden olyan életveszélyes vagy krónikus leépüléssel járó betegség, melynek előfordulási aránya a népességen belül az 1/2000 aránynál kisebb, ritka betegségnek minősül (EURORDIS, 2007).

A pszichés fejlödés szempontjából sérülékeny gyermekek közé tartoznak a különböző rizikótényezők miatt preventív ellátásra jogosultak. E mögött állhatnak egyéni, főképpen biológiailag meghatározott sajátosságok, mint például a születéskori éretlenség, a tápláltsági állapot, és állhatnak környezeti rizikótényezők, mint például a szülő ártó nevelési eszközei, a családban történt negatív életesemények. A lelki egészség szempontjából fontos a prevenció, a megelőző szolgáltatásnyújtás. A kora gyermekkori intervenciónak ki kell terjednie a rizikótényezők jelenlétével terhelt gyermekek körére, a gyermekek fejlődésének követése mellett cél kell, hogy legyen a korai lelki egészségvédelem fókuszba állitása (Kereki és Szvatkó, 2015).

A szociálisan hátrányos helyzet különböző kategóriáinak kritériumait a gyermekvédelmi törvény tartalmazza. Ennek alapján hátrányos helyzetü az a rendszeres gyermekvédelmi kedvezményre jogosult gyermek és nagykorúvá vált gyermek, akinek esetében az alábbi körülmények közül egy fennáll: (1) a szülö(k) vagy a családba fogadó gyám alacsony iskolai végzettsége, (2) a szülő vagy a családba fogadó gyám alacsony foglalkoztatottsága, (3) a gyermek elégtelen lakókörnyezete. Halmozottan hátrányos helyzetü (a) az a rendszeres gyermekvédelmi kedvezményre jogosult gyermek és nagykorúvá vált gyermek, akinek esetében a szülő (gyám) alacsony iskolai végzettségére, az alacsony foglalkoztatásra vagy az elégtelen lakókörnyezetre vonatkozó kitételek közül legalább kettő fennáll, (b) a nevelésbe vett gyermek, (c) az utógondozói ellátásban részesülő és tanulói vagy hallgatói jogviszonyban álló fiatal felnőtt [1997. évi XXXI. törvény a gyermekek védelméről és a gyámügyi igazgatásról, 67/A. \$ (1)]. 
A kora gyermekkori intervenció és fejlesztési lépései

Kiemelten tehetséges gyermek (tanuló), aki átlag feletti általános vagy speciális képességek birtokában magas fokú kreativitással rendelkezik, és felkelthetö benne a feladat iránti erös motiváció, elkötelezettség [2011. évi CXC. törvény a nemzeti köznevelésről, 4 . $\$$ 14.]. Protokoll alapján a gyermekek 3 éves kortól kapják meg ezt a szolgáltatást (Izsóné Szecsődi és Hujber, 2015).

\section{A korai beavatkozások jelentősége}

A korai életszakaszra irányuló prevenciós, intervenciós tevékenységek fontossága több szinten is indokolható. Egyrészt az egyén, másrészt a család, harmadrészt a társadalom szintjén.

Az egyén jólléte, életminősége szempontjából nagy jelentősége van az egészséges fejlődés támogatásának, az időben nyújtott prevenciós és intervenciós szolgáltatásoknak. A korai években szerzett tapasztalatok beépülnek a testünkbe, az agyi struktúrák kialakulása, fejlődése és a környezetből jövő ingerek, a gyermeket körülvevő gondoskodó kapcsolatok interaktívan hatnak egymásra. A megfelelő mennyiségű és minőségű szenzoros és mozgásos élmények, a biztonságos kapcsolatok, a szociális hatások együttesen alapozzák meg az egészséges agyi fejlődést és a komplex képességek kialakulását (Shonkoff és Phillips, 2000). A várandósság időszaka mellett mindenekelőtt a születéstől az 5 éves korig terjedő első néhány életév az, amely különösen érzékeny periódus a fejlődés folyamatában. Az egészséges fejlődést számos tényező veszélyeztetheti, a biológiai károsodások, a kedvezőtlen szocioökonómiai jellemzők, az optimális környezeti feltételek hiánya, az érzelmi, pszichés sérülések, az elhanyagoltság külön-külön és együttesen is befolyásolhatják. Fontos tehát, hogy a megfelelő beavatkozások minél előbb történjenek meg, hiszen komoly hatással lehetnek, arra, hogy a későbbiekben az állapot enyhébb kimenetű legyen vagy akár tünetmentessé váljon.

2010-2011-ben egy, a Tárki-Tudok kutatóintézet által végzett kutatás kapcsán 764 fó 0-6 éves életkorú, különböző ellátó intézményben terápiás, korai fejlesztő, habilitációs/rehabilitációs ellátásban lévő gyermek bemeneti és kimeneti eredményeit megvizsgálva azt találtuk, hogy a gyermekek állapotjavulására az intézménybe való bekerülési életkor, a bekerülési állapot, a kezdöterápia heti óraszáma, illetve a terápiás folyamatban való szülöi részvétel hat leginkább. Bár a gyakorlatban a szakemberek nap mint nap megtapasztalják, a kutatási adatok is egyértelmüen mutatják, hogy minél korábban kerül be a gyermek az ellátásba, annál nagyobb az esélye az állapotjavulásra. Ha egy gyermek egy évvel később kerül ellátásba, mint hasonló állapotú társai, akkor szignifikánsan csökken az állapotjavulás esélye. Ha a gyermek középsúlyos állapotban kerül be az intézménybe, szignifikánsan kisebb esélye van az állapotjavulásra, mint enyhe állapotú társainak (egy a háromhoz az esélye). A súlyos és halmozottan sérült gyermekeknél ez a hatás még erősebb, csak egy a tízhez (1:10-hez) az esélyük a javulásra enyhe állapotú társaikhoz képest. Minél magasabb a kezdö terápiás folyamatban a gyermek (illetve családja) ellátására forditott heti óraszám, annál valószinübb, hogy a gyermek állapota javul. Annak a gyermeknek, akinek a szülei az egész folyamat során részt vettek a terápiás foglalkozásokon, jelentösen nagyobb lesz az esélye az állapotjavulásra, mint akinél legfeljebb egy terápiás szakaszban vettek részt a szülők (Kereki, 2011). Ez utóbbi eredmény megerősíti annak a szemléleti megközelítésnek a létjogosultságát, amely a családközpontúságot, valamint a szülő és terapeuta együttmüködését hangsúlyozza a kora gyermekkori intervencióban.

A családok szintjén is megmutatkozik a beavatkozások pozitív hatása: nő a család összetartó ereje, olyan erősségek kerülnek felszínre közös életükben, amelyek korábban nem voltak nyilvánvalóak a család számára. A szülők magabiztosabbakká válnak, jobban felismerik gyermekük erősségeit, képességeit, (speciális) szükségleteire megtanulnak adekvát választ adni. Nő a jogismeretük, egyre inkább képesek érdekeiket, illetve gyermekük érdekeit képviselni, segítséget kapnak abban, hogy integrálódjanak a közösség életébe (Bailey és mtsai, 2006). 
Mindezeken túl fontos hangsúlyozni a korai életszakaszban nyújtott prevenciós és intervenciós támogatások társadalmi szintü következményeinek jelentőségét. A társadalmi szintű hatások komplex, egymást erősítő módon jelentkeznek, hiszen a kedvezőbb kimenetű egyéni életutak összességében egy jobban múködő társadalmat eredményeznek, ugyanakkor ez a fajta társadalmi hasznosság hosszú távú gazdasági nyereséggel is jár. Az Amerikai Egyesült Államokban az 1960-as években számos longitudinális vizsgálat indult, amelyek bizonyos gyermekcsoportokra irányuló korai beavatkozások hatásait kezdték vizsgálni. Az eredmények azt mutatták, hogy a program hatására hosszantartó nyereségek azonosíthatóak a vizsgált gyermekek tanulmányi előrehaladásában és eredményeiben, a későbbi munkaerőpiaci kimenetelekben, a szociális függőség csökkenésében (pl. mennyire szorul rá a személy szociális segélyre) és a proszociális viselkedésekben (Karoly, Kilburn és Cannon, 2005). A társadalmi haszon többek között a bünelkövetések és a serdülőkorú anyaság gyakoriságának jelentős csökkenésében, valamint a biztos állással és stabil családi háttérrel rendelkezők számának növekedésében is detektálható (Heckman és Masterov, 2007).

Amellett, hogy a kora gyermekkori intervenció elősegíti a gyermek és a család társadalmi integrációját, a hosszútávú gazdasági hasznosság szempontjából is kiemelkedő jelentőségű. James Heckman amerikai Nobel díjas közgazdász, aki a kora gyermekkori befektetések költség-haszon elemzésével foglalkozott, az alábbi következtetésre jutott:

„A bizonyitékok teljesen világosan mutatják, hogy humán képességek fejlödésében tapasztalt egyenlötlenség minden szinten olyan negatív társadalmi és gazdasági hatással jár, amit csak a kora gyermekkori nevelésbe történö befektetéssel tudunk, illetve kell tudnunk megelözni, különösen igaz ez a hátrányos helyzetü gyermekek és családjuk esetében." (Heckman, 2011. 31. o.)

J. J. Heckman és munkatársai az említett longitudinális vizsgálatokhoz kapcsolódva a korai évekbe való befektetések hosszútávú megtérülését vizsgálták. Carneiro és Heckman (2003) szerint, ha a gyermek születésétől követjük az emberi tőkébe való befektetések megtérülési mértékét, megállapítható, hogy az iskoláskor előtti beruházások megtérülési rátái magasabbak, mint a későbbi életszakaszokban történő beruházásoké. Később a várandósság időszakát is bevonták a vizsgálati körbe, a hipotetikus megközelítés alapján a fogantatástól a születésig történő befektetések megtérülési rátái még magasabbak, mint a születés után megkezdett beavatkozásoké (Doyle és mtsai, 2009).

\section{A kora gyermekkori intervenció nemzetközi trendjei}

A kora gyermekkori intervenció területe gyorsan fejlődik, számos fejlődési irány azonosítható, amelyek három nagy csomópont köré csoportosíthatóak: a családközpontúság, az interdiszciplináris teamtevékenység és az inkluzív közösségalapú szolgáltatások hangsúlyaihoz.

A csak a gyermekre fókuszáló megközelités a múlté, mára már a családfókuszú megközelités vált követendő gyakorlattá, a gyermek mellett a család, sőt annak környezete is a szolgáltatások középpontjába kerül (Bernheimer \& Weisner, 2007; Coulthard, 2009). A hatékony és eredményes munka érdekében elengedhetetlen a szülők bevonása, a velük való partneri együttmüködés kialakítása, a családra irányuló figyelem előtérbe helyezése. Ez a trend összekapcsolódik az ökológiai rendszerszemléletü modell térnyerésével, amely a család müködésének izolációs modellje helyett a család működését a szűkebb és a tágabb környezet kontextusában értelmezi (Bronfenbrenner, 1994). A deficitorientált megközelitést az erösségalapú megközelités váltotta fel, a gyermek problémájára irányuló figyelem helyett a gyermek és a család erősségeinek és erőforrásainak támogatására helyeződött a hangsúly (Turnbull, Turbiville $\mathcal{E}$ Turnbull, 2000). A hazai szakemberek körében is elfogadásra talált ez a gondolat, a gyógypedagógia szemléletében alapvetően 
detektálható, de a védőnők is egyre inkább emlegetik az erősségalapú gondozás szükségességét, a kisgyermeknevelők körében terjed az erősségalapú gondozás-nevelés, az óvodapedagógusok vonatkozásában pedig az erősségalapú nevelés gondolata.

A korábban jellemző multidiszciplináris teammüködéstöl az interdiszciplináris teammunkán keresztül a transzdiszciplináris megközelitésü teamtevékenység vált követendővé (Carpenter, 2000; Rapport, McWilliam E Smith, 2004; Moore, 2004; Drennan, Wagner E Rosenbaum, 2005). Ez segítette annak folyamatát, hogy a széttöredezett szolgáltatásoktól elmozdulás történjen a holisztikus megközelitésü egységes integrált szolgáltatások felé (Guralnick, 2008). A nemzetközi tapasztalatok azt mutatják, hogy a koordinált, interdiszciplináris együttműködésen alapuló, integrált szolgáltatói hálózatok hatékonyabban müködnek (KPMG, 2014; Moore, 2011). Ugyanakkor a multiszektoriális megközelítéstől az interszektoriális (ágazatok közötti) megközelítés irányába történő elmozdulás integráltabb szolgáltatásnyújtást eredményez (Engle és mtsai, 2011; Neuman E Devercelli, 2013; KPMG, 2014; Woodhead és mtsai, 2014).

A szegregált központhoz rendelt szolgáltatásoktól elmozdulás történt az inkluzív közösség-alapú szolgáltatások felé. A gyermeket körülvevő akadályok, korlátozó tényezők leküzdéséhez elengedhetetlen, hogy a környezet megközelíthető, elérhető, a gyermek szükségleteihez igazított legyen, megfelelő szociális támogatással, minden diszkriminációt nélkülözve. A megfelelő tárgyi és személyi feltételek biztosítják a gyermek természetes környezetben való optimális működésének és fejlődésének elősegítését. Ugyanakkor fontos az is, hogy a szakemberek együttműködjenek a szülőkkel. A családközpontú gyakorlat és a magas minőségű technikai támogatás szükséges annak érdekében, hogy a családok a gyermekük számára annak fejlődését, tanulását elősegítő élményeket, megfelelő ingerekkel teli környezetet tudjanak biztosítani (Moore, 2011, 2012).

\section{Rövid hazai helyzetkép}

A hazai kora gyermekkori intervenciós intézményrendszer szereplői mindazok az egészségügyi, köznevelési, szociális, gyermekjóléti, gyermekvédelmi, illetve egyéb intézmények, valamint dolgozóik, akik a fogantatástól a gyermek iskolába kerüléséig a gyermekekkel (beleértve a speciális támogatást igénylő gyermekeket), illetve családjaikkal kapcsolatba kerülnek. Munkájuk a rendszer működésének különböző szakaszaihoz, a felismerés, szűrés, jelzés folyamatához, az állapotmegismerés, diagnosztika szakaszához, valamint a terápiás, fejlesztő, habilitációs/rehabilitációs ellátások, szolgáltatások, valamint juttatások, rendszeréhez kapcsolódik (Kereki, 2011).

A gyermek útja az egészségügyi ellátórendszerben kezdődik, a korai életszakaszban leginkább ebben a kontextusban írható le. Minden szakaszban megtalálhatóak azok a különböző ágazati hovatartozás alá tartozó kulcsintézmények, ellátásban részt vevő szereplők, akiknek feladatai jogszabály által meghatározottak. Az egyes ágazatokon belül a továbbküldési és jelzési utak viszonylag követhetőek a jogszabályok alapján, de a különböző ágazati irányítás alá tartozó intézményes szereplőket csak részlegesen köti össze szabályozott gyermekút. Különösen az egészségügyi ellátók felől a köznevelési intézményrendszer felé vezető utakra jellemző az esetlegesség. A speciális támogatások kapcsán az egészségügyi szakellátásnak bizonyos életkorig (a gyermek 18 hónapos koráig) van a pedagógiai szakszolgálat felé közvetlen küldési lehetősége [Lásd 15/2013. (II. 26.) EMMI rendelet a pedagógiai szakszolgálati intézmények müködéséröl, 4. S (2)]. A pedagógiai szakszolgálati rendeletben felsorolt szakellátó szakorvosok (a neonatológia, csecsemő és gyermek fül-orr-gégegyógyászat, audiológia, szemész, ortopédia és traumatológia, gyermek- és ifjúságpszichiátria, fizikális medicina és rehabilitációs orvoslás, orvosi rehabilitáció csecsemő- és gyermekgyógyászat szakterületen, illetve gyermek-neurológia szakorvos) által felállított diagnosztikai vélemény alapján korai fejlesztést javasolhatnak a gyermeknek. A pedagógiai szakszolgálat szakértői bizott- 
sága a szakértői véleményét a szakorvos által felállított diagnosztikai vélemény és terápiás javaslat alapján is elkészítheti. Érdekesség, hogy ezt a lehetőséget egyetlen egészségügyi jogszabály sem tartalmazza, az érintett orvosok többnyire a pedagógiai ellátóktól értesülnek arról, hogy ezt megtehetik.

Ugyanakkor az egészségügyi alapellátásból nem vezet szabályozott út a köznevelés felé. A védőnők, házi gyermekorvosok, vegyes praxisú háziorvosok tájékozottságuktól függően küldik a pedagógiai szakszolgálathoz a gyermeket és a családot. Legnehezebb helyzetben a 3 év alatti gyermekek vannak, hiszen, ha nem kerül problémájuk az egészségügyi alapellátók vagy a gyermekjólét látókörébe, nem biztos, hogy továbbkerülnek a megfelelő ellátó intézménybe. Még ha az alapellátó szakemberek észlelik is a problémát, előfordul, hogy a szülő nem tudja megoldani az ellátásba jutást, akár anyagi, akár közlekedési nehézségek miatt, vagy egyéb családi okból. Az is előfordulhat, hogy a szülő nem akar szembesülni a problémával, vagy egyszerüen tájékozatlansága okán nem foglalkozik a gyanújelekkel. Amikor intézménybe, például bölcsődébe kerül a gyermek, akkor továbbjutásának útja nagyobb eséllyel biztosított.

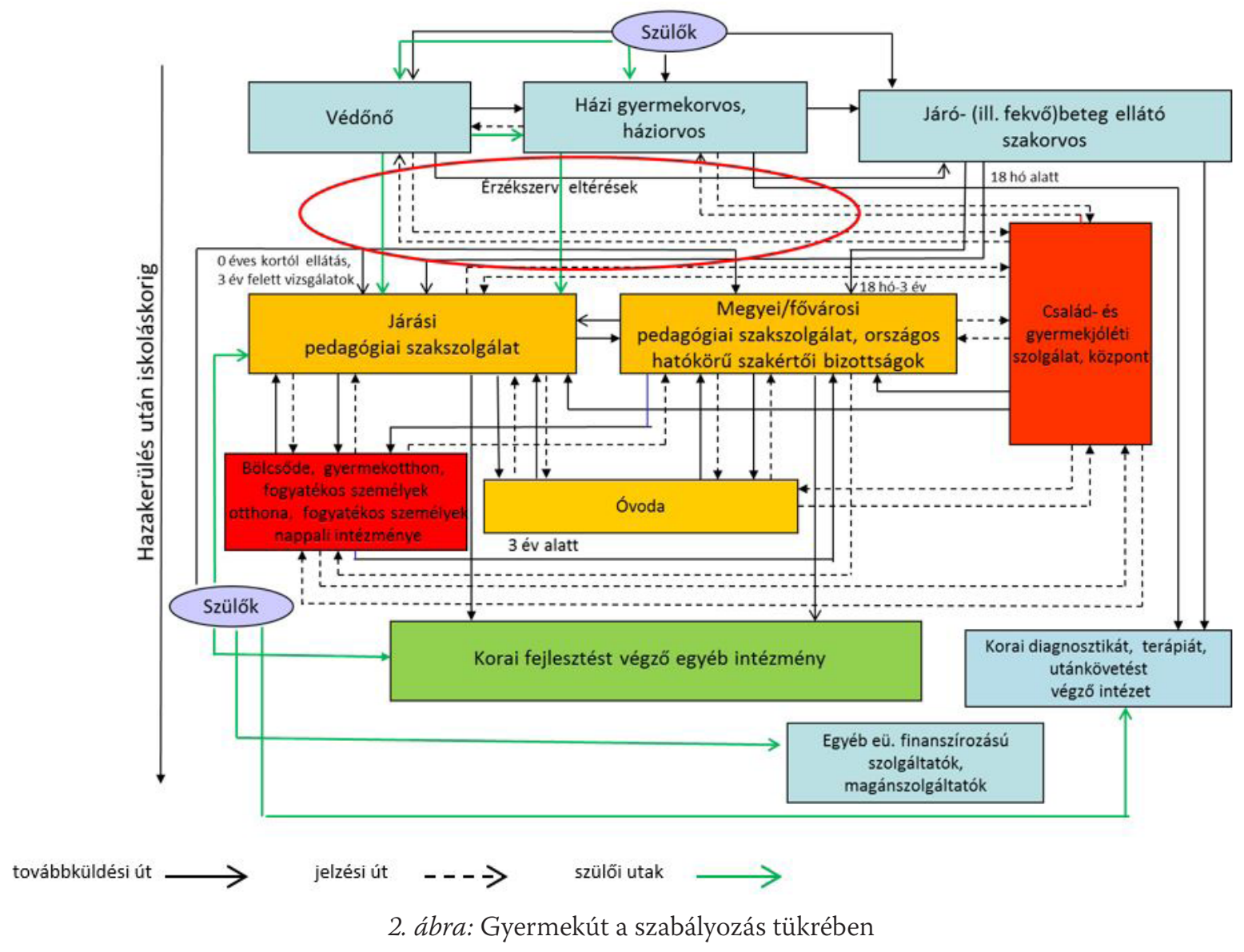

A széttöredezett intézményrendszer, a szabályozatlan utak, illetve a megfelelő út hiánya bolyongásra készteti a szülőket az ellátórendszerben (lásd 2. ábra). Így előfordulhat, hogy olyan intézménybe, szolgáltatóhoz is eljuthat, ahol megfelelő állapotmegismerés, diagnózis nélkül kezdik meg a gyermek fejlesztését, nélkülözve a megfelelő, szükségletalapú ellátást. Mindez az egységes szemléletű, megfelelően koordinált ellátás hiányáról árulkodik, amely mögött többek között a szabályozási, finanszírozási környezet elégtelensége és a különböző szinteken azonosítható együttműködések gyengesége húzódik meg. A szakemberek nem ismerik egymás kompetenciáit, illetve ezek a kompetenciák nem tisztázottak. A szülők és a szakemberek egyaránt információhiánnyal küzdenek. Mindhárom ágazatban jellemző a minőségi standardok hiánya, a szakmai kontroll gyengesége, de a szisztematikus mérés és 
A kora gyermekkori intervenció és fejlesztési lépései

visszacsatolás sem működik megfelelően. Továbbra is hiányoznak a korszerü, standardizált szürési módszerek, vizsgáló eljárások. A kora gyermekkori intervencióban részt vevő szakemberek korai ellátással kapcsolatban megszerzett tudása egyenetlen, képzésbeli hiányosságok tapasztalhatók (lásd részletesen Kereki, 2013, 2015, 2017).

\section{Fejlesztési lépések}

Az említett problémák megoldására több mint tíz éves kutató, fejlesztő munka eredményeképpen 2017 februárjától egy négy éves, átfogó, komplex fejlesztési elképzelést magába foglaló kora gyermekkori intervenciós ágazatközi projekt indult el, amely a különféle ágazatok háttérintézményeinek konzorciumi együttműködésében valósul meg². A projekt célja az iskoláskor előtti gyermekek és családjaik hatékonyabb, magasabb színvonalú ellátásához, a szükségletekhez jobban igazodó szolgáltatásokhoz való hozzájutásának biztosítása, különös tekintettel a speciális ellátási szükségletű csoportokra. A projekt elsődleges céljának elérése érdekében a legfontosabb feladat az egységes gyermekút kialakitása. Ennek érdekében a szakemberek körében a kora gyermekkori intervencióról való egységes szemlélet kialakitása, a tudásbázis növelése a cél, a rendszer minden szereplőjére kiterjedő, nagy volumenű képzések biztosításával. Az eredményes müködést a szülők és a szakemberek partneri kapcsolatának támogatásával, a szülöi kompetenciák szélesítésével kívánja elérni a projekt. Az ellátási egyenlőtlenségek csökkentését a gyermekekkel foglalkozó szolgáltatásokhoz való hozzáférés javítása, a szolgáltatásoknak a szolgáltatáshiányos területekre való eljuttatása hivatott elősegíteni.

\footnotetext{
2 A konzorcium vezetője a Család- és Ifjúságügyért felelős Államtitkársághoz kapcsolódó Családbarát Ország Nonprofit Közhasznú Kft., konzorciumi partnerei a köznevelés területéről a Klebelsberg Központ és az Oktatási Hivatal, az egészségügyet a Nemzeti Népegészségügyi Központ, a szociális területet a Szociális és Gyermekvédelmi Főigazgatóság képviseli. A megvalósításban partnerként szerepel még a Magyar Államkincstár.
}

A projekt közvetlen célcsoportjai a kora gyermekkori intervenciós ellátásban résztvevő különböző szakemberek (többek között gyógypedagógusok, pszichológusok, házi gyermekorvosok, vegyes praxisú háziorvosok, szakellátó szakorvosok, védőnők, gyógytornászok, kisgyermeknevelők, óvodapedagógusok, szociális munkások stb.), illetve a kisgyermekek és családjaik. Közvetetten a születéstől az iskolába lépésig terjedő életkorban lévő gyermekekre és családjaikra irányul a projekt, különös tekintettel a speciális támogatást igénylő gyermekekre és családjaikra.

\section{Rendszerszintü fejlesztések, módszertani támogatás}

A projekt keretében lezajlik a kora gyermekkori intervenciót érintő ágazati jogszabályok felülvizsgálata és összehangolása is, ez teremti meg az ellátórendszer jogszabályi müködési környezetét. Az intézményrendszer hatékonyabb működéséhez kialakításra került egy egyértelműen követhető, szabályozott gyermekút, amely pontról pontra tartalmazza a különböző ellátási szükségletű (beleértve az eltérő, megkésett fejlődésű vagy annak kockázatának kitett) gyermekek és családjuk továbbküldési útjait. Ehhez szorosan kapcsolódik az egészségügyi alapellátásban, szakellátásban résztvevő szakemberek, valamint a szociális, gyermekvédelmi, gyermekjóléti terület, illetve a köznevelés releváns szereplői, valamint a kora gyermekkori intervenció egyéb résztvevői közötti együttműködés erősítése, a kompetenciák és feladatok lehatárolása, a köztük lévő kommunikáció támogatása.

A gyermekút akkor tud igazán müködni, ha megfelelő informatikai háttér biztosítja a gyermekek fejlődésének, ellátásának nyomon követését. Ezért sor kerül a különböző ágazatok informatikai szakrendszereit (pl. az Országos Védőnői Informatikai Rendszert, a pedagógiai szakszolgálatok által használt Integrált Nyomonkövető Rendszert vagy a Központi Elektronikus Nyilvántartás a Szolgáltatást Igénybevevőkről rendszert) öszszekapcsoló informatikai háttér kiépítésére, amelynek segítségével javul és felgyorsul a 
különböző ágazati szakrendszerek közötti információáramlás, segítve a köznevelési, szociális és egészségügyi ágazatok szakembereinek munkáját. A különböző szakterületek számára szükséges adattartalmak lehatárolása és a jogosultsági szintek meghatározása teszi egyértelművé a használati lehetőségeket. Hosszútávú tervek között szerepel a bölcsődei szakrendszer kialakítása.

A hozzáférésben megmutatkozó egyenlötlenségekre tekintettel a projekt kiemelten kezeli a születéstől az iskolába lépésig tartó időszakban a gyermekek és családjaik szolgáltatáshoz való hozzáférésének támogatását. Ennek érdekében vállalta elsősorban a szociálisan hátrányos helyzetű területeken élők számára a szolgáltatások helybe való eljuttatásának elősegítését. Egy olyan komplex, mozgó szolgáltatói modell került kidolgozásra, amely a szolgáltatáshiányos területeken koordinált, a területspecifikus szükségletek lefedésével müködő hálózatot hoz létre, és 100 településen nyújt szolgáltatást a hiányzó szűrések, vizsgálatok és a terápiás, fejlesztő ellátások lebonyolításával.

A szakemberek módszertani támogatása érdekében olyan gyakorlatközpontú kézikönyvek kerültek kidolgozásra, amelyek a kora gyermekkori intervenció három nagy szakaszához kapcsolhatók. Így a felismerést segíti majd elsősorban az alapellátásban dolgozó szakemberek (kisgyermeknevelők, óvodapedagógusok, szociális munkások) számára a gyermeki fejlődésről, az eltérő fejlődés gyanújeleiről, valamint a hétköznapi nevelési helyzetekről és azoknak megoldásáról, a szülők támogatásának lehetőségeiről szóló ismeretek összefoglalása. Elsősorban a pedagógiai szakszolgálatok szakembereit célozza meg a fejlődési zavarok korai szürésének, azonosításának, állapotmegismerésének, diagnosztikájának módszertana, illetve a korai komplex családközpontú tanácsadás, korai fejlesztés, gondozás, terápiás ellátás témaköréhez készülő kézikönyv.

A közös gyermekutat támogató irányelvek, protokollok kerültek kidolgozásra, többek között egy olyan egészségügyi irányelv, amely a perinatális/neonatális intenzív centrumokba bekerült koraszülött gyermekek utógondozásának egységes eljárásrendjét tartalmazza. A köznevelés területén az óvodában használt szűrőeszközök egységes rendszerének kialakítását célzó protokoll, a mozgásfejlesztő és mozgásterápiás eljárások használatának egységes protokollja, illetve egy korszerü iskolába lépési protokoll került kialakításra. Ezek a protokollok kapcsolódnak azokhoz a korszerü mérőeszközökhöz, amelyek fejlesztésére a projekt keretében sor került, pl. az iskolakészültségi vizsgálat vagy a szenzoros integrációs vizsgálóeljárás. A bölcsődékben és az óvodákban ellátott gyermekek fejlődésének nyomonkövetésére egységes mérőeszköz készült, az úgynevezett gyermekfejlődési kérdőív kisgyermeknevelőknek (0-2 éves korosztály), illetve óvodapedagógusoknak (3-7 éves korosztály). A mérőeszköz kis mintán és nagy mintán bemért, validált mérőeszköz, amelyet 2020-ban ad át a projekt az érintettek számára.

\section{Szakemberek, szülök kompetenciáinak fejlesztése}

Az ágazatközi projektben 19 képzés került kifejlesztésre, 10000 fö szakember továbbképzését vállalva fel, jórészt kiscsoportos, tréningesített foglalkozás keretében, másrészt távoktatás formájában. A képzések ingyenes, akkreditált, minősített pontszerző továbbképzések, amelyek mindhárom ágazat képzési rendszereiben akkreditálásra, illetve minősítésre kerültek.

A gyermeki fejlődésről, az fejlődési eltérések felismeréséről, illetve az ellátórendszer müködéséről, az egységes gyermekútról, az interdiszciplináris teammunkáról való tudás széles körű elterjesztése a kora gyermekkori intervencióban részt vevő szakemberek kompetenciáinak növelését, egységes szemléletük formálását célozza. Ennek jegyében a projekt módszertani fejlesztéseinek nagy része komplex képzésekbe csatornázódik be, és a különböző szakterületeken dolgozó szakemberek részére vegyes kis csoportokban kerül megszervezésre, kiaknázva az ily módon történő ismeretszerzés szemléletformáló erejét. A 
képzési tartalom átadása mellett a képzéseken nem titkolt cél az informális kapcsolati háló kiépítése a résztvevő szakemberek között, amely az együttműködés hatékony kiépítését és fenntartását hivatott szolgálni. Emellett témaspecifikus képzések keretében ismerkednek meg a szakemberek pl. a fejlesztésre kerülő szűrő és vizsgáló eljárásokkal vagy a korai komplex családközpontú tanácsadás, intervenció témájával. Célcsoport-specifikus képzésben vesznek részt pl. a kisgyermeknevelők, óvodapedagógusok a pedagógiai tanácsadás témakörében. A szemléltetést és az információk vizuális úton való továbbítását a projekt keretében készülő 100 db rövid oktató film segíti.

A rendszerszintű megközelítés jegyében hangsúlyos szempontként jelenik meg a legfontosabb képzési tartalmak graduális képzésbe való becsatornázása is. Ennek érdekében a különböző szakterületek felsőoktatási képző intézményeinek képviselői rendszeresen összehívott mühelymunkák keretében egyeztetik és összehangolják a kora gyermekkori intervencióra vonatkozó közös képzési kimeneteket, tudástartalmakat és dolgoznak a projekt eredményeinek a graduális képzésbe való beemelésén. Mind a pedagógusképzés (csecsemő- és kisgyermeknevelő, óvodapedagógus, gyógypedagógus és konduktor), mind a bölcsészettudományi (pszichológus) és a társadalomtudományi (szociális munkás, szociálpedagógus), valamint az egészségtudományi szakok gyógytornászokat képző intézményei egyaránt részt vesznek ebben a folyamatban.

Mindezeken túl a szakemberek mentálhigiénés támogatásban is részesülnek, szupervíziós és esetmegbeszélő csoportokban vehetnek részt, a szakmákat tekintve vegyes csoportos keretekben.

A projekt fontos feladatnak tartja a korai ellátásban részt vevő szakemberek mellett az iskoláskor előtti gyermekek szüleinek edukálását, a kora gyermekkori fejlődéssel, illetve gyermekneveléssel kapcsolatos ismereteik bővítését, a megfelelő szülői kompetencia, tudatosság és felelősségérzet erősítését. A kora gyermekkori intervenció egyik sarkala- tos pontja a szolgáltatásokhoz való mielőbbi hozzáférés elősegítése. Ezért lényeges a szülők számára az ellátórendszer, a gyermekút megismerése, az ellátórendszerhez kapcsolódó tudás bővítése. Fontos szempont az is, hogy nemcsak a szakemberek számára szükséges az egységes tudás megszerzése, a szülőknek ugyanezt a tudást a megfelelő „szülői nyelven" kell tudni átadni ahhoz, hogy a szakemberek és szülők között a közös tudásra épülő együttműködés kialakulhasson. Az ismeretek átadását a családok részére készített tájékoztató anyagok támogatják, honlap segíti az elektronikus információátadást, interaktív módon mutatva be a különböző jogosultsági csoportok esetében a követendő ellátási utat. A mentálhigiénés támogatás keretében új módszertani megközelítésben szülő - szakember esetmegbeszélő csoportok, illetve a kompetencia szélesítése érdekében tipikus fejlődésű gyermeket nevelő szülők és családtagjaik, valamint eltérő, megkésett fejlődésű gyermekek szülei és családtagjai számára indulnak szülőképző csoportok.

\section{Összefoglalás}

A kora gyermekkori intervenció elméleti kereteinek tisztázása a különböző ágazatok és szakterületek egységes szemléletű megközelítését szolgálja. A magyarországi ellátórendszer átalakításánál nemcsak a hazai problémák azonosítása ad diagnosztikus kiindulási pontot a fejlesztéshez, de ismernünk kell az általános nemzetközi trendeket, valamint meg kell ismernünk azokat a működő modelleket, amelyeknek adaptálható elemeit felhasználhatjuk egy hatékonyabb és eredményesebb intézményrendszer kialakításához. A szakmák közötti együttmüködésben az esetleges kapcsolódások helyett a szabályozott „gyermekút" létrehozása jelenti a megoldást. A szakemberek képzésében a kora gyermekkori intervencióval kapcsolatos tudástartalmak fejlesztése, a különböző szakterületek és ágazatok közötti együttműködéssel kapcsolatos ismeretek elsajátítása mellett egyértelműen szükség van a család kompetenciáinak széle- 
sítésére is. Elengedhetetlen a területi adottságoknak megfelelően a koordinált szolgáltatásokhoz való hozzáférés javítása, az ágazatközi interdiszciplináris teamek működtetése.

A kora gyermekkori intervenció ágazatközi fejlesztése projekt megvalósítása várhatóan egy több és színvonalasabb szolgáltatást magában foglaló, hatékonyabban müködő ellátórendszert eredményez, ahol átlátható, nyomon követhető gyermekút biztosítja a szakemberek és a szülők számára is az egyértelmű továbblépési lehetőségekről való tudást. Ugyanakkor a szolgáltatáshiányos területek is ellátáshoz jutnak, csökkennek a területi ellátásbeli egyenlőtlenségek. A képzések eredményeként nő a kora gyermekkori intervencióban részt vevő szakterületek szakembereinek kompetenciája, egységes tudása, ismertté válnak számukra a közös gyermekúthoz kapcsolódó szakmai elvárások, továbbküldési, jelzési utak. A szülők informáltabb, elégedettebb, gyermeküket jobban ismerö, kompetensebb szülőkké válnak. Ez lehetővé teszi számukra, hogy felismerjék az „elég jó szülőség” értékeit, tudatosabban azonosítsák és támogassák gyermekeik erősségeit, képességeit, szükségleteire adekvátabb válaszokat adjanak, és jobban eligazodjanak az ellátórendszerben.

\section{Felhasznált irodalom}

Bailey, D. B., Bruder, M. B., Hebbeler, K., Carta, J., Defosset, M., Greenwood, C., Kahn, L., Mallik, S., Markowitz, J., Spiker, D., Walker, D. és Barton, L. (2006): Recommended Outcomes for Families of Young Children with Disabilities. Journal of Early Intervention, 28., 226-251. https://doi.org/10.1177/105381510602800401

Bernheimer, L. C. és Weisner, T. S. (2007): 'Let me just tell you what I do all day...' The faamily Story at the center of intervention research and practice. Infants and Young Children, 20. 3. sz., 192-201. https://doi.org/10.1097/01.IYC.0000277751.62819.9b

Bronfenbrenner, U. (1994): Ecological models of human development. International Encyclopedia of Education, Vol. 3, 2nd. Ed. Elsevier, Oxford. Reprinted In: Gauvain, M. \& Cole, M. (eds.) Readings on the development of children, 2nd Ed. (1993, 37-43). Freeman, New York.

URL: http://edfa2402resources.yolasite.com/ resources/Ecological\%20Models\%20of\%20 Human\%20Development.pdf[2019. 10. 30.]

Busse, R., Blümel, M., Scheller-Kreinsen, D. \& Zentner, A. (2010): Tackling Chronic Disease in Europe. World Health Organization.

URL: http://www.euro.who.int/_data/assets/ pdf_file/0008/96632/E93736.pdf?ua=1 [2019. 10. 20.]

Carneiro, P. \& Heckman, J. J. (2003): Human Capital Policy. In: Heckman, J. \& Krueger, A. (eds.) Inequality in America: What Role for Human Capital Policy? MIT Press, 77-240. https://doi.org/10.3386/w9495

Carpenter, B. (2000): Sustaining the family: Meeting the needs of families of children with disabilities. British Journal of Special Education, 27. 3. sz., 135-144.

https://doi.org/10.1111/1467-8527.00176

Coulthard, N. (2009): Service Trends and Practitioner Competencies in Early Childhood Intervention: A review of the literature. Victorian Chapter of Early Childhood Intervention Australia (ECIA).

URL: http://www.eciavic.org.au/documents/ item/26 [2019. 10. 15.]

Doyle, O., Harmon, C. P., Heckman, J. J. \& Tremblayd, T. R. (2009): Investing in Early Human Development: Timing and Economic Efficiency. Economics \& Human Biology, 7. 1. sz., 1-6. https://doi.org/10.1016/j.ehb.2009.01.002

Drennan, A., Wagner, T. \& Rosenbaum, P. (2005): The ,Key Worker' Model of Service Delivery. Keeping Current \#1-2005. CanChild Centre for Disability Research, Hamilton, Ontario.

Engle, P. L., Fernald, L. C. H., Alderman, H., Behrman, J., O'Gara, C., Yousafzai, A., Cabral de Mello, M., Hidrobo, M., Ulkuer, N., and the Global Child Development Steer Group (2011): „Strategies for reducing inequalities and improving developmental outcomes for young children in low-income and middleincome countries." The Lancet, Early Online Publication, 23 September 2011. https://doi. org/10.1016/S0140-6736(11) 60889-1.

EURORDIS (2007): What is a Rare Disease? EURODIS. https://www.eurordis.org/sites/ default/files/publications/Fact_Sheet_RD.pdf [2019. 10. 27.] 
A kora gyermekkori intervenció és fejlesztési lépései

Guralnick, M. J. (2008): International perspectives on early intervention: A search for common ground. Journal of Early Intervention, 30. 1. sz., 90-101.

https://doi.org/10.1177/1053815107313483

GYEMSZI (2013): A krónikus betegek ellátásának jellemzői Európában. Gyógyszerészeti és Egészségügyi Minőség- és Szervezetfejlesztési Intézet.

URL: https://era.aeek.hu/zip_doc/kutatas/ 2013/kronikus_ellatas_nemzetkozi_v3.pdf [2019. 10. 20.]

Heckman, J. J. \& Masterov, D. V. (2007): The productivity argument for investing in young children. Working Paper 13016. National Bureau of Economic Research. 1050 Massachusetts Avenue Cambridge, MA 02138, April 2007. https://doi.org/10.3386/w13016

Heckman, J. J.(2011): The Economics of Inequality: The Value of Early Childhood Education. American Educator, 35. 1. sz., 31-35,

Izsóné Szecsődi Ildikó és Hujber Tamásné (2015): A kiemelten tehetséges gyermekek, tanulók gondozásának szakszolgálati protokollja. Educatio Társadalmi Szolgáltató Nonprofit Kft., Budapest.

URL: https://iskolataska.educatio.hu/media/ szakszolgalatok/tehetseg_nyomda.pdf [2019. 10. 28]

Karoly, L. A., Kilburn, M. R. és Cannon, J. S. (2005): Early Childhood Interventions. Proven Results, Future Promise. RAND Corp., Santa Monica, Arlington, Pittsburgh.

https://doi.org/10.7249/MG341

Kereki Judit (2011, írta és szerk.): Regionális helyzetértékelés a kora gyermekkori intézményrendszer hálózatos fejlesztésének megalapozásához. Kutatási zárójelentés. Educatio Társadalmi Szolgáltató Nonprofit Kft., Budapest.

URL: http://www.educatio.hu/pub_bin/ download/tamop_311/4piller/regionalis helyzetertekeles_kezirat.pdf [2019. 10. 15.]

Kereki Judit (2015, szerk.): Kliensút Kalauz. Educatio Társadalmi Szolgáltató Nonprofit Kft., Budapest.

Kereki Judit (2017): Utak: A kora gyermekkori intervenció rendszerszintü megközelítése. ELTE Eötvös Kiadó; ELTE Bárczi Gusztáv Gyógypedagógiai Kar, Budapest.

Kereki Judit és Szvatkó Anna (2015): A koragyermekkori intervenció, valamint a gyógypeda- gógiai tanácsadás, korai fejlesztés, oktatás és gondozás szakszolgálati protokollja. Educatio Társadalmi Szolgáltató Nonprofit Kft., Budapest.

KPMG (2014): Early childhood intervention - an overview of best practice. KPMG International Cooperative.

URL: https://docplayer.net/7618068-Earlychildhood-intervention-an-overview-of-bestpractice.html [2019. 10. 05.]

Moore, T. G. (2004): Blazing new trails: Finding the most direct routes in early childhood intervention. In: Proceedings of the Sixth Biennial National Conference of Early Childhood Intervention Australia, 25-27 July 2004, Melbourne, Victoria.

URL: http://www.rch.org.au/uploadedFiles/ Main/Content/ccch/TM_ECIAConf04_ Blazing_new_trails.pdf [2019. 10. 29.]

Moore, T. G. (2011): Early childhood intervention reform project. Executive summary. Revised literature review December 2010. Programs and Partnerships Division Department of Education and Early Childhood Development, Melbourne.

Moore, T. G. (2012). Rethinking early childhood intervention services: Implications for policy and practice. Pauline McGregor Memorial Address presented at the 10th Biennial National Conference of Early Childhood Intervention Australia, and the 1st Asia-Pacific Early Childhood Intervention Conference, Perth, Western Australia, 9th August.

URL: http://www.rch.org.au/uploadedFiles/ Main/Content/ccch/profdev/ECIA_National_Conference_2012.pdf [2019. 10. 27.]

Neuman, M. J. \& Devercelli, A. E. (2013): What Matters Most for Early Childhood Development: A Framework Paper. Systems Approach for Better Education Results (SABER) working paper series; no. 5. World Bank, Washington, DC. (c) World Bank.

URL: https://openknowledge.worldbank. org/bitstream/handle/10986/20174/9018 30NWP0no5000B ox385307B00PUBLIC0. pdf? sequence $=1$ \&isAllowed $=y$ [2019. 10. 11.]

Rapport, M. J., McWilliam, R. A. \& Smith, B. J. (2004): Practices Across Disciplines in Early Intervention. The Research Base. Infants and Young Children, 17. 1. sz., 32-44.

https://doi.org/10.1097/00001163-200401000-00006

Shonkoff, J. P. \& Phillips D. A. (2000): From neurons to neighbourhood. The science of early 
childhood development. National Academy Press, Washington.

Turnbull, A. P., Turbiville, V. \& Turnbull, H. R. (2000): Evolution of family-professional partnerships: Collective empowerment as the model for the early twenty-first century. In: Shonkoff, J. P. \& Meisels, S. J. (eds.): Handbook of Early Childhood Intervention. Cambridge University Press, Cambridge, Massachusetts, 630-650. https://doi.org/10.1017/CBO9780511529320.029

WHO (2005): Preventing Chronic Diseases a vital investment. World Health Organization, Geneva.

URL: http://www.who.int/chp/chronic disease_report/contents/foreword.pdf [2019. 10. 20.]
Woodhead, M. Feathersone, I.; Bolton, L. \& Robertson, P. (2014): Early Childhood Development: Delivering Intersectoral Policies, Programmes and Services in Lowresource Settings. Topic guide, November (2014). Health \& Education Advice \& Resource Team (HEART), Oxford.

\section{Jogszabályok}

2011. évi CXC. törvény a nemzeti köznevelésről

1997. évi XXXI. törvény a gyermekek védelméről és a gyámügyi igazgatásról

15/2013. (II. 26.) EMMI rendelet a pedagógiai szakszolgálati intézmények müködéséről

\section{Steps of early childhood intervention and development}

All children included those with special needs and their families are receiving services according to their concrete special needs provided by the early childhood intervention system. Prevention and intervention services provided in the early years are of utmost importance both for the development of the child and the future of the society. The definition of the early childhood intervention's theoretical framework, a summary of the international trends, the description of the structure of the Hungarian system and the present state of cooperation between the intersectoral actors are all contribute to the clear understanding of the elements of the institutional system developments. The Intersectoral Development of Early Childhood Intervention project is targeting the cross-sectoral improvement of early childhood intervention. It is built upon the international experience as well as previous research and developmental results and its main result will be the definition of a unified, clear and transparent "child-path" in the system.

Keywords: prevention, early childhood intervention, intersectoral cooperation, regulated child-path in the system, integrated and coordinated service provision system, interdisciplinary team 